\section{Eating at high elevation: an herbivorous beetle from alpine rock outcrops relies on ammonia- absorbing lichens}

\author{
John Marris, ${ }^{1}$ David Hawke ${ }^{2,3,5}$, And David GlennY ${ }^{4}$ \\ Manuscript received 10 October 2018; revised 8 November \\ 2018; accepted 3 December 2018. Corresponding Editor: John \\ Pastor. \\ ${ }^{1}$ Bio-Protection Research Centre, Lincoln University, PO \\ Box 85084, Lincoln 7647 New Zealand. \\ ${ }^{2}$ Ōtautahi Isotope Research Unit, 135 Halswell Junction \\ Road, Christchurch 8025 New Zealand. \\ ${ }^{3}$ Department of Science and Primary Industries, Ara \\ Institute of Canterbury, PO Box 540, Christchurch 8140 New \\ Zealand. \\ ${ }^{4}$ Allan Herbarium, Manaaki Whenua Landcare Research, \\ PO Box 69040, Lincoln 7647 New Zealand. \\ ${ }^{5}$ Corresponding author; e-mail: david55.isotope@gmail.com
}

Citation: Marris, J., D. Hawke, and D. Glenny. 2019. Eating at high elevation: an herbivorous beetle from alpine rock outcrops relies on ammonia-absorbing lichens. Ecology 00(00):e02598. 10.1002/ecy.2598

Key words: alpine; ammonia; Brontini; flightless beetle; lichen; New Zealand; Protodendrophagus antipodes; rock outcrop; Silvanidae; stable isotope analysis.

The flightless endemic New Zealand beetle, Protodendrophagus antipodes Thomas 2003 (Coleoptera: Silvanidae: Brontinae: Brontini; Fig. 1a, b), is unique among its tribe of 12 globally distributed genera in exchanging the forest for an alpine existence. Until recently, $P$. antipodes was thought to be rare, known only from a handful of specimens from above the tree line in mountains in the northern part of New Zealand's South Island. Following the discovery of the beetle's favored habitat of alpine rock outcrop crevices (Fig. 1c), they have been found by J. Marris at 19 of 24 localities examined, along much of the $700 \mathrm{~km}$ length of the South Island mountains and from $1,500 \mathrm{~m}$ to over 2,000 m elevation.

Excepting $P$. antipodes, the larvae of the Brontini consume fungi found underneath loose bark (Thomas 2003). Since $P$. antipodes lives well above the tree line, a tree-based fungal diet is clearly impossible. Lichens are composite organisms arising from a complex fungal symbiosis (Spribille et al. 2016). The abundance of lichens in typical $P$. antipodes habitat, and in some instances, the absence of any obvious alternative food source, suggested to us that lichen consumption could then be the dietary link between $P$. antipodes and the remaining fungivorous Brontini.

We attempted to test our lichen consumption hypothesis with gut analysis using microscopy. Unfortunately, we were stymied by a predominance of unrecognizable amorphous material; the only identifiable items were scattered ascospores of the crustose lichens Rhizocarpon geographicum (L.) DC. and either Buellia ocellata (Flotow) Körber or B. aethalea (Ach.) Th.Fr. Although the presence of these ascospores matched expectations for a lichen diet, the amorphous material remained a puzzle. We then turned to an indirect method, the measurement of carbon and nitrogen stable isotope ratios $\left({ }^{13} \mathrm{C} /{ }^{12} \mathrm{C},{ }^{15} \mathrm{~N} /{ }^{14} \mathrm{~N}\right.$; reported as $\left.\delta^{13} \mathrm{C}, \delta^{15} \mathrm{~N}\right)$. Stable isotope analysis has had particular success in elucidating trophic relationships of arthropods in hard-to-observe contexts, including those in alpine areas (Steinwandter et al. 2018).

Our samples for stable isotope analysis came from 1,718 to $1,805 \mathrm{~m}$ elevation on $\mathrm{Mt}$. Hutt ski field $\left(43^{\circ} 29.692^{\prime} \mathrm{S}, 171^{\circ} 32.706^{\prime} \mathrm{E}\right.$; Fig. 1d), at the eastern edge of New Zealand's Southern Alps. Rock outcrops at the study site had patches of crustose lichens alongside pockets of vascular plants, mosses, as well as foliose and fruticose lichens growing in crevices and other sheltered microhabitats. At each of three outcrops encompassing $300 \mathrm{~m}$ across a steep scree slope, we collected 5-10 adult and larval $P$. antipodes along with a sample of soil and each of the commonly found mosses, lichens, and vascular plants (see Fig. 2 for species list). Salticid spiders, as known predators from habitats where $P$. antipodes is found, provided a trophic comparison for $P$. antipodes isotope data. The invertebrates (with their abdomens removed to eliminate gut contents), plant foliage, and soil were analysed in an automated continuous flow isotope ratio mass spectrometer using two-point normalization against international standards. Quality control used standard materials prepared separately by the laboratory and D. Hawke (Hawke et al. 2018).

Animals have $\delta^{15} \mathrm{~N}$ values higher than their food, the difference in $\delta^{15} \mathrm{~N}$ values between an invertebrate consumer and its diet being remarkably constant at $2.5 \pm 0.2 \%$ (Caut et al. 2009). The high $\delta^{15} \mathrm{~N}$ values for the salticids (Fig. 2) matched their expected role as a high trophic level predator, confirming that we were not dealing with some isotopically aberrant system. Primary producer $\delta^{15} \mathrm{~N}$ values at our sites fell into two clusters $12 \%$ apart (Fig. 2); crustose and fruticose lichens 


Article e2598; page $2 \quad$ THE SCIENTIFIC NATURALIST Ecology, Vol. xx, No. xx

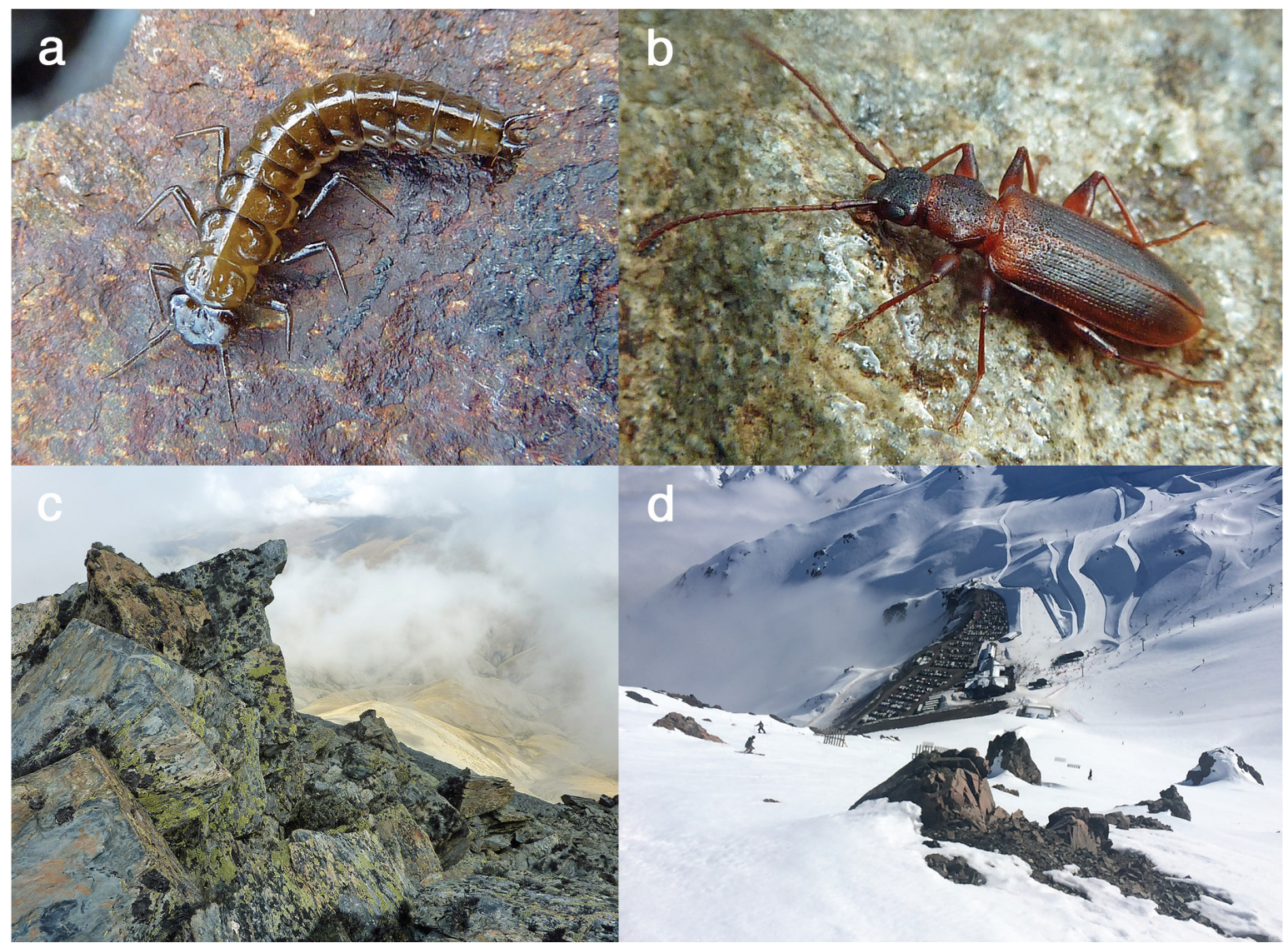

FIG. 1. (a) Larval and (b) adult Protodendrophagus antipodes. (c) their alpine rock outcrop habitat, and (d) exposed outcrops on the Mt. Hutt ski field sampling site in winter. Adult beetles are typically 7-10 $\mathrm{mm}$ long.

centered at $-15.1 \%$ and mosses, vascular plants, and foliose lichens at $-3.0 \%$. At $-10 \%$ to $-14 \%$, adult and larval $P$. antipodes $\delta^{15} \mathrm{~N}$ values were $1-3 \%$ higher than crustose and fruticose lichens and so consistent with these lichens as the most probable primary food source. In contrast, beetle $\delta^{15} \mathrm{~N}$ values were much lower than those for mosses, vascular plants, foliose lichens, and soil, eliminating these as potential food sources.

For $\delta^{13} \mathrm{C}$, the difference between an animal and its food is usually small. The $\delta^{13} \mathrm{C}$ values for $P$. antipodes were intermediate between crustose and fruticose lichens. Consequently, the combined isotopic results pointed to one or both of these lichens as the primary nutrition for $P$. antipodes. The link to the other fungiconsuming beetles from the tribe Brontini is therefore through the fungal symbionts of lichen, as we suspected. However, lichens are rich in secondary compounds that deter herbivory (Asplund and Wardle 2017), so the challenge for $P$. antipodes is then to process their food. The inference of larval $P$. antipodes feeding on crustose and fruticose lichens is isotopically secure. However, the indication that adults also depend on lichens is contingent on continued protein turnover even though growth and development has ceased.

Despite 400,000 described beetle species in over 100 families, lichen feeding has only rarely been documented. Furthermore, records of lichen feeding by beetles, such as among the families Byrrhidae, Zopheridae, Tenebrionidae, and Curculionidae, represent only occasional instances of dietary shifts from an otherwise general pattern of plant or fungal feeding (Hammond and Lawrence 1989). Larvae are the major feeding stage in beetle life cycles and, therefore, better reflect the adaptations of species to a particular food type (Lawrence 1989). One notable example of feeding on lichens is the anthribid weevil Lichenobius littoralis Holloway, 1970, whose larvae form feeding tunnels just below the surface of supralittoral, rock-encrusting lichens (Holloway 1971). Lichen feeding in $P$. antipodes is apparently a unique occurrence among the Brontini, and perhaps the entire family Silvanidae. Our results are one of the few unequivocal examples of lichen feeding in beetle larvae, and highlight the value of stable isotope analysis in assessing arthropod food sources. 


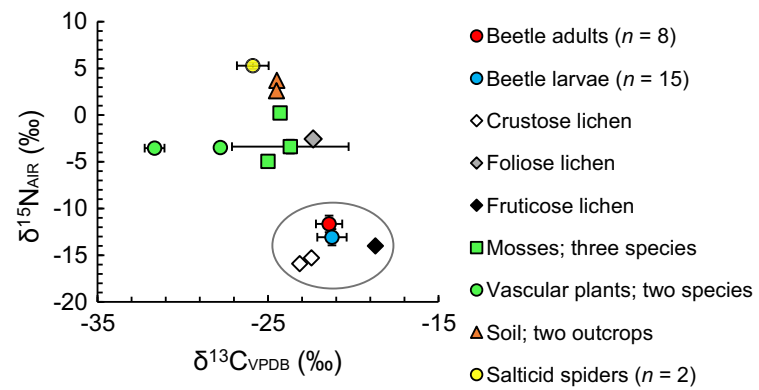

FIG. 2. Plot of $\mathrm{C}$ and $\mathrm{N}$ isotope ratios (as delta values) for Protodendrophagus antipodes adults and larvae and their ecological context, showing the wide range in $\delta^{15} \mathrm{~N}$. The circled data highlight the extremely low $\delta^{15} \mathrm{~N}$ values found for $P$. antipodes and their likely diet of crustose and fruticose lichens. Error bars show SD; where error bars are not shown for $\delta^{15} \mathrm{~N}$ values, this is due to errors being smaller than symbol size. Plant and lichen list: Crustose lichen, Rhizocarpon geographicum (L.) DC.; foliose lichen, Xanthoparmelia flavescentireagens (Gyeln.) D.J. Galloway (species uncertain); fruticose lichen, Usnea acromelana Stirt.; mosses, Racomitrium ptychophyllum (Mitt.) Hook.f. or R. striatipilum Cardot, Weissia controversa Hedw., and Distichium capillaceum (Hedw.) Bruch \& Schimp.; vascular plants, Raoulia bryoides Hook.f. and Dracophyllum pronum W.R.B. Oliv.

Lacking the root system of vascular plants, lichens depend for their $\mathrm{N}$ on either atmospheric deposition or, less often, atmospheric $\mathrm{N}_{2}$ fixation (Asplund and Wardle 2017). Nitrogen fixing plants typically have $\delta^{15} \mathrm{~N}$ values close to zero, while plants using ammonium ions usually have $\delta^{15} \mathrm{~N}$ values close to that of the source ammonium (Högberg 1997). Typical atmospheric ammonia $\delta^{15} \mathrm{~N}$ values increase from gaseous ammonia $(-20 \%)$, to wet deposition ammonium $(-2 \%)$, and particulate ammonium $(+20 \%)$ (Ti et al. 2018). The remarkably negative $\delta^{15} \mathrm{~N}$ values of the crustose and fruticose lichens (Fig. 2) at our site therefore best matched gaseous ammonia as the predominant $\mathrm{N}$ source.

Protodendrophagus antipodes adults and larvae are a widespread but cryptic element of the macroinvertebrate community on alpine rock outcrops along the South Island of New Zealand. Our finding that $P$. antipodes primarily consume ammonia-absorbing lichens at our Mt. Hutt study site prompts two contrasting ecological questions. Firstly, the source of the ammonia is unknown. Potential sources include the sea $100 \mathrm{~km}$ upwind to the west, intensive agriculture on the plains immediately to the east, and until their recent extirpation, surface-nesting river bird colonies in nearby alpine areas (Stead 1927, Tozer et al. 2005, Riddick et al. 2016, $\mathrm{Ti}$ et al. 2018). Finally, there is the broader question of the part played by $P$. antipodes in the ecology of its alpine environment. The role of landscape-scale physical processes in supporting biodiversity and shaping productivity is well known from studies of beach-cast tidal wrack (Polis et al. 2004). If $P$. antipodes is a significant prey animal for alpine lizards, birds and predatory arthropods, this unusual member of the tribe Brontini would comprise an important conduit for lichens and atmospheric ammonia in supporting indigenous alpine biodiversity.

\section{ACKNOWLedgments}

John Elix (Australian National University, Australia) kindly identified lichen spore material. Sarah Bury and Julie Brown (NIWA Environmental Stable Isotope Laboratory, New Zealand) carried out the stable isotope analysis. Sophie Marris prepared Fig. 1, and Adrian Paterson (Lincoln University, New Zealand) and two anonymous reviewers provided useful commentaries on our draft manuscript.

\section{Literature Cited}

Asplund, J., and D. A. Wardle. 2017. How lichens impact on terrestrial community and ecosystem properties. Biological Reviews 92:1720-1738.

Caut, S., E. Angula, and F. Courchamp. 2009. Variation in discrimination factors $\left(\Delta^{15} \mathrm{~N}\right.$ and $\left.\Delta^{13} \mathrm{C}\right)$ : the effect of diet isotopic values and applications for diet reconstruction. Journal of Applied Ecology 46:443-453.

Hammond, P. M., and J. F. Lawrence. 1989. Appendix. Mycophagy in insects: a summary. Pages 275-324 in N. Wilding, N. M. Collins, P. M. Hammond, and J. F. Webber, editors. Insect-fungus interactions. 14th Symposium of the Royal Entomological Society of London in collaboration with the British Mycological Society. Academic Press, London, UK.

Hawke, D. J., J. C. S. Brown, and S. J. Bury. 2018. The prevention and detection of human error in ecological stable isotope analysis. Methods in Ecology and Evolution 9:2326-2333.

Högberg, P. 1997. ${ }^{15} \mathrm{~N}$ natural abundance in soil-plant systems. New Phytologist 137:179-203.

Holloway, B. A. 1971. Entomology of the Aucklands and other islands south of New Zealand: Coleoptera: Anthribidae. Pacific Insects Monograph 27:261-270.

Lawrence, J. F. 1989. Mycophagy in the Coleoptera: feeding strategies and morphological adaptations. Pages 1-23 in N. Wilding, N. M. Collins, P. M. Hammond, and, and J. F. Webber editors. Insect-fungus Interactions. 14th Symposium of the Royal Entomological Society of London in collaboration with the British Mycological Society. Academic Press, London, UK.

Polis, G. A., F. Sánchez-Piñero, P. T. Stapp, W. B. Anderson, and M. D. Rose. 2004. Trophic flows from water to land: marine input affects food webs of islands and coastal systems worldwide. Pages 200-216 in G. A. Polis, M. E. Power, and G. R. Huxel, editors. Food webs at the landscape level. University of Chicago Press, Chicago, Illinois, USA.

Riddick, S., D. Ward, P. Hess, N. Mahowald, R. Massad, and E. Holland. 2016. Estimate of changes in agricultural terrestrial nitrogen pathways and ammonia emissions from 1850 to present in the Community Earth System Model. Biogeosciences 13:3397-3426.

Spribille, T., et al. 2016. Basidomycete yeasts in the cortex of ascomycete macrolichens. Science 353:488-492.

Stead, E. F. 1927. Native and introduced birds of Canterbury. Pages 204-225 in R. Speight, A. Wall, and R. M. Laing, 
editors. The natural history of Canterbury. Philosophical Institute of Canterbury, Christchurch, New Zealand.

Steinwandter, M., A. Rief, S. Scheu, M. Traugott, and J. Seeber. 2018. Structural and functional characteristics of high alpine soil macro-invertebrate communities. European Journal of Soil Biology 86:72-80.

Thomas, M. C. 2003. The Brontini of the world: a generic review of the tribe (Coleoptera: Silvanidae: Brontinae). Insecta Mundi 17:1-31.
Ti, C., B. Gao, Y. Luo, X. Wang, S. Wang, and X. Yan. 2018. Isotopic characterization of $\mathrm{NH}_{\mathrm{x}}-\mathrm{N}$ in deposition and major emission sources. Biogeochemistry 138:85-102.

Tozer, W. C., D. Hackell, D. B. Miers, and W. B. Silvester. 2005. Extreme isotopic depletion of nitrogen in New Zealand lithophytes and epiphytes, the result of diffusive uptake of atmospheric ammonia? Oecologia 144:628-635. 